\title{
Persistent metabolic syndrome and risk of cardiovascular disease in children and adolescents
}

\author{
Síndrome metabólica infanto-juvenil persistente e relação com o risco de doença cardiovascular
}

Síndrome metabólico infantojuvenil persistente y relación con el riesgo de enfermedad cardiovascular

\section{Camilla Ribeiro Lima de Farias', Carla Campos Muniz Medeiros', Diogo Rodrigues Souza', Ivelise Fhrideraid Alves Furtado da Costa', Mônica Oliveira da Silva Simões', Danielle Franklin de Carvalho'}

' Universidade Estadual da Paraíba. Campina Grande, Paraíba, Brazil.

How to cite this article:

Farias CRL, Medeiros CCM, Souza DR, Costa IFAF, Simões MOS, Carvalho DF. Persistent metabolic syndrome and risk of cardiovascular disease in children and adolescents. Rev Bras Enferm [Internet]. 2018;71(3):1013-21.

DOI: http://dx.doi.org/10.1590/0034-7167-2016-0564

Submission: 01-24-2017 Approval: 05-23-2017

\begin{abstract}
Objective: to verify persistence of metabolic syndrome (MetS) and components in overweight children and adolescents, as well as its relation to socioeconomic and demographic characteristics and to the Pathobiological Determinants of Atherosclerosis in Youth (PDAY) score. Method: a two-point longitudinal study: at enrollment and after a 24-month interval, with 133 individuals ages from two to 18 years. The demographic anthropomorphic and blood variables were evaluated. Analysis was carried out by simple and paired association tests, as well as multiple logistic regression. Results: persistent MetS was observed in $38.3 \%$ of the sample, associated cardiovascular risk (ACR) in 79.7\%, reduction in arterial pressure and do HDL-c. After adjusting for age and sex, excess weight (ExpB: 0.182; Cl: 0.059-0.561), low HDL-c (ExpB: 9.247; Cl: 1.157-73.930) and high LDL-C (ExpB:1.915; Cl: 0.921-3.979) were associated with persistent MetS. Conclusion: persistent MetS was associated with obesity, HDL-c and LDL-C, but not with the PDAY score.
\end{abstract}

Descriptors: Metabolic X Syndrome; Cardiovascular Diseases; Obesity; Adolescent; Child.

\section{RESUMO}

Objetivo: verificar a persistência da síndrome metabólica (SM) e componentes em crianças e adolescentes com excesso de peso, além de sua relação com características socioeconômicas, demográficas e com o escore Pathobiological Determinants of Atherosclerosis in Youth (PDAY). Método: estudo longitudinal com dois pontos: recrutamento e 24 meses com 133 indivíduos entre dois e 18 anos. Foram avaliadas variáveis socioeconômicas, demográficas, antropométricas e sanguíneas. Realizouse análise através de testes de associação simples e pareado, além de regressão logística múltipla. Resultados: verificou-se persistência de SM em 38,3\% da amostra, risco cardiovascular associado (RCV) em 79,7\%, redução da pressão arterial e do HDL-c. Ajustados por idade e sexo, o excesso de peso (ExpB: 0,182; IC: 0,059-0,561), o baixo HDL-c (ExpB: 9,247; IC: 1,157-73,930) e o elevado LDL-c (ExpB:1,915; IC: 0,921-3,979) mostraram-se associados à SM persistente. Conclusão: a SM persistente teve associação com o excesso de peso, HDL-c e LDL-c, mas não com o escore PDAY.

Descritores: Síndrome X Metabólica; Doenças Cardiovasculares; Obesidade; Adolescente; Criança.

\section{RESUMEN}

Objetivo: Verificar persistencia del síndrome metabólico (SM) y componentes en niños y adolescentes con exceso de peso, además de su relación con características socioeconómicas, demográficas y con el puntaje de Pathobiological Determinants of Atherosclerosis in Youth (PDAY). Método: Estudio longitudinal con dos ítems: reclutamiento y 24 meses con 133 individuos de entre 2 y 18 años. Evaluadas variables socioeconómicas, demográficas, antropométricas y sanguíneas. Realizado análisis mediante tests de asociación simple y pareada, además de regresión logística múltiple. Resultados: Se verificó persistencia de SM en 38,3\% de muestra, riesgo cardiovascular asociado (RCV) en 79,7\%, reducción de presión arterial y HDL-c. Ajustados por edad y sexo, el exceso de peso (ExpB: 0,182; IC: 0,059-0,561), el bajo HDL-c (ExpB:9,247; IC:1,157-73,930) y el elevado 
LDL-c (ExpB:1,915; IC: 0,921-3,979) se mostraron asociados a la SM persistente. Conclusión: El SM persistente estuvo asociado al exceso de peso, HDL-c y LDL-c, pero no con el puntaje PDAY.

Descriptores: Síndrome X Metabólico; Enfermedades Cardiovasculares; Obesidad; Adolescente; Niño.

CORRESPONDING AUTHOR Camilla Ribeiro Lima de Farias E-mail: camilla_ribeiro@hotmail.com

\section{INTRODUCTION}

Brazil is currently undergoing economic, social and demographic changes, with repercussions on living, health and working conditions, including the diet of the population. This process has been marked by nutritional and epidemiological transitions that contribute to the increase in chronic noncommunicable diseases (CND), which affect more and more young individuals on a global scale $\mathrm{e}^{(1-3)}$. In developing countries, the prevalence of overweight and obesity in the child and adolescent population has increased, reaching $12.9 \%$ of boys and $13.4 \%$ of girls in $2014^{(4)}$. Thus, there was also an increase in the occurrence of metabolic syndrome (MetS) and cardiovascular diseases (CVD), very frequently in associated forms.

Although there is no consensus for the diagnosis of MetS in children and adolescents, it is accepted that the coexistence of three or more cardiometabolic risk factors, such as arterial hypertension, abdominal adiposity, hypertriglyceridemia, reduction of HDL-cholesterol (high density lipoprotein cholesterol) and glucose intolerance or type 2 diabetes mellitus (DM2), characterizes its presence ${ }^{(5-6)}$, it may or may not be associated with inadequate lifestyle, socioeconomic condition, sedentarism, physical inactivity and smoking ${ }^{(7)}$.

MetS has been responsible for the majority of cardiovascular events, the risk for which increases with early onset and duration of the syndrome ${ }^{(8-10)}$. Nevertheless, there is late diagnosis, with a tendency for the risk factors associated with the syndrome to persist over time. Brazil has been presenting an increase in MetS among the young and especially in the obese (the prevalence in the interior of the Northeast is $21.3 \%$ and $36.2 \%$ in João Pessoa, capital of Paraíba), with a consequent increase in CVD ${ }^{(11)}$ The PDAY cardiovascular risk score (Pathobiological Determinants of Atherosclerosis in Youth) ${ }^{(12)}$ is a global risk algorithm including multiple risk factors, such as sex, age, serum lipoprotein concentrations, smoking, hypertension, obesity, and hyperglycemia. It was developed with the purpose of estimating the probability of atherosclerotic lesions in adolescents and young adults ${ }^{(13)}$; with physical inactivity and sedentarism as aggravating risk factors ${ }^{(14-16)}$.

As can be seen, overweight and obesity in the early stages of life is increasing, with correspondingly higher cardiometabolic risk factors and consequent occurrence of metabolic syndrome and cardiovascular disease. Considering the importance of this public health problem and the scarcity of studies in Brazil investigating this relationship, the present study was conducted to evaluate the persistence of metabolic syndrome and its relation to cardiovascular risk in the juvenile population.

\section{OBJECTIVE}

To verify the persistence of metabolic syndrome (MetS) and its components in overweight children and adolescents, in addition to its relationship with socioeconomic and demographic characteristics as well as with the Pathobiological Determinants of Atherosclerosis in Youth (PDAY) score.

\section{METHOD}

\section{Ethical aspects}

The study was approved by the Research Ethics Committee of the Universidade Estadual da Paraíba (UEPB).

\section{Study design local and period}

This was a longitudinal study carried out in two phases, at enrollment and then after 24 months, in the Childhood Obesity Center, in the city of Campina Grande, Pernambuco State, from March 2008 to April 2012.

\section{Sample and inclusion and exclusion criteria}

Using convenience sampling, 133 children and adolescents were recruited who met the following criteria; overweight or obese; a user of the Unified Health System (SUS), age between 2 and 18 years at the beginning of the study; and signed the Term of Free and Informed Consent. Exclusion criteria were: presence of renal, hepatic or other morbidities and/or use of drugs that compromise the glucose and lipid metabolism; an alteration (temporary or permanent) that impairs locomotion or participation in any stage of the study; and cases requiring drug intervention. No losses were recorded.

\section{Study protocol}

A form was used to collect the following demographic information: (age, gender, color), socioeconomic (maternal education level, income) and lifestyle (physical activity, physical inactivity and smoking). Blood pressure, blood collection for determination of total cholesterol, HDL and LDL fractions, triglycerides, fasting blood glucose and glycosylated hemoglobin $\mathrm{HbA} 1 \mathrm{c}$ were performed. The latter was the final stage.

\section{Data collection and analysis}

For statistical analysis, the variables were classified as categorical: age range (2 to 9 and 10 to 19 years), sex (male and female); color (white and non-white) ${ }^{(17)}$, maternal education level ( $\leq 8$ and $>8$ years of schooling), income ( $\leq 1$ and $>1$ minimum wage), physical activity (PA) (inactive / insufficiently active I: <150 minutes/week and insufficiently active II/active: $\geq 150$ minutes/week) (14) and sedentarism ( $<2$ hours/day TV time $>$ "screen time"hours/ day) ${ }^{(16)}$. Smoking (at least one cigarette/day in the last six months) was not categorized because no case was recorded ${ }^{(18)}$.

Anthropometry was performed according to WHO recommendations $^{(19)}$. The weight was measured using a Welmy ${ }^{\circledR}$ digital scale, stature with Tonelli stadiometer and abdominal circumference (AC) with Cardiomed $^{\circledR}$ inelastic measuring tape. AC was classified as altered when $\geq 90$ th percentile for 
age and $\operatorname{sex}^{(20)}$, but with a maximum limit of $88 \mathrm{~cm}$ for girls and $102 \mathrm{~cm}$ for boys ${ }^{(21)}$.

The nutritional status was determined according to the body mass index (BMI), which establishes the ratio of weight (in kilograms) to the square of height (in meters). It is classified by z-score, according to age and sex: underweight $(-3 \leq$ z-score $<-2)$, normal $(-2 \geq$ z-score $<+1)$, overweight $(+1$ $\geq$ z-score $<+2$ ), obese (z-score $\geq+3)^{(22)}$. For those over 18 years of age, the cut-off points of BMI (in $\mathrm{kg} / \mathrm{m}^{2}$ ) were underweight $(<17.5)$, normal ( $\geq 17.5 \mathrm{BMI}<25)$, overweight $(\geq$ $25.0 \mathrm{BMI}<30.0)$ and obese $(\geq 30.0)^{(23)}$.

Blood pressure (BP) was measured using the Tycos ${ }^{\circledR}$ mercury sphygmomanometer, following the procedures of the Brazilian Hypertension Directive $\mathrm{VI}^{(24-25)}$. The biochemical variables necessary to classify metabolic syndrome and the construction of the PDAY cardiovascular risk score were evaluated. Blood collection was performed after 12 hours of fasting, in the Clinical Analysis Laboratory of the State University of Paraíba (LAC/ UEPB). Total cholesterol (TC), HDL-cholesterol (HDL-c), triglycerides (TG), and fasting blood glucose (FG) were evaluated by enzymatic colorimetric method (BioSystems $310^{\circledR}$ ), according to the manufacturer's recommendations for the Labtest ${ }^{\circledR}$ kit. LDL-C was determined by the Friedewald formula: LDL-C $=$ TC-HDL-C$\mathrm{TG} / 5$, valid for TG values of less than $400 \mathrm{mg} / \mathrm{dL}$, and non-HDLc for the difference between TC and HDL-c ${ }^{(26)}$.

MetS diagnosis was performed according to the criteria recommended by the NCEP/ATPIII ${ }^{(27)}$, adapted for age group, which considers the presence of at least three of these criteria: $A C \geq$ 90th percentile for gender, height and age; triglycerides $\geq$ $100 \mathrm{mg} / \mathrm{dL} ; \mathrm{HDL}-\mathrm{c}<45 \mathrm{mg} / \mathrm{dL}$, FG $\geq 100 \mathrm{mg} / \mathrm{dL}$, systolic and/or diastolic pressure above or at the 90th percentile for sex, height and age. MetS was categorized as "MetS Negative" (no MetS at the two points evaluated); "intermittent MetS" (MetS in one of the points); "persistent MetS" (MetS in both evaluation points). Risk was classified as "low risk" for individuals with a score $\leq 0$, "moderate risk" between 1 and 4 and "high risk" $\geq 5^{(13)}$.
Statistical analysis was carried out with SPSS version 22.0. The Chi-square test $\left(x^{2}\right)$ was used to evaluate the association of categorical variables. Next, McNemar's test was used to verify the behavior of the clinical and biochemical variables, as well as the presence of MetS at the moment of enrollment and then at 24 months. Simple regression analysis was also performed to test the association of socioeconomic, demographic, lifestyle, clinical and biochemical variables with the persistence of MetS and its components with the PDAY cardiovascular risk score.

After this step, two logistic regression models were constructed, adopting the inclusion of all variables method. The first model, included the variables that presented association $p$ $\leq 0.20$ (age, nutritional status, non-HDL-cholesterol and blood pressure), in order to estimate the probability of persistent MetS occurring as a function of these variables. In the second, persistence and components of MetS were treated as independent variables and the PDAY cardiovascular risk score (low and moderate/high) as the dependent variable. Except for logistic regression, the alpha ( $\alpha$ ) error rate was set at $5 \%$ in all analyses.

\section{RESULTS}

The sample, at the time of enrollment and after 24 months, comprised 133 children and adolescents. The majority were female $(60.9 \%)$, non-white $(67.7 \%)$, with a family income above one minimum wage $(86.5 \%)$ and eight or less years of maternal schooling (55.6\%). The distribution according to age group, at enrollment, was 54 (40.6\%) children and 79 (59.4\%) adolescents. After two years, 10 children had progressed into the adolescent group.

Twenty-six individuals (19.5\%) were classified as MetS negative, 56 (42.1\%) intermittent MetS and 51 (38.3\%) persistent MetS. At the end of the study, there was a significant reduction in the percentage of changes in systolic and diastolic pressures, exactly on the contrary to HDL-cholesterol, with a greater percentage below desirable levels (Table 1). HbA1c was evaluated only after a 24 months, with no at this point (5.2 $\pm 0.4 \%)$.

Table 1 - Clinical and biochemical characteristics of metabolic syndrome at the point of enrollment and after 24 months, Childhood Obesity Center, Campina Grande, Paraíba, Brazil, 2009/2012

\begin{tabular}{|c|c|c|c|c|c|}
\hline \multirow{2}{*}{ Variable } & \multicolumn{2}{|c|}{ Enrollment } & \multicolumn{2}{|c|}{ Month 24} & \multirow{2}{*}{$p$ value } \\
\hline & $\mathbf{n}$ & $\%$ & $\mathbf{n}$ & $\%$ & \\
\hline \multicolumn{6}{|c|}{ Metabolic syndrome (NCEP/ATPIII) } \\
\hline Present & 82 & 61.7 & 81 & 60.9 & \multirow{2}{*}{1.00} \\
\hline Absent & 51 & 38.3 & 52 & 39.1 & \\
\hline \multicolumn{6}{|l|}{ Nutritional state (z-score) } \\
\hline Obesity & 108 & 81.2 & 102 & 76.7 & \multirow{2}{*}{0.46} \\
\hline Overweight* & 25 & 18.2 & 31 & 23.3 & \\
\hline \multicolumn{6}{|l|}{ Waist circumference $(\mathrm{cm})$} \\
\hline Altered & 86 & 64.7 & 94 & 70.7 & \multirow{2}{*}{0.22} \\
\hline Normal & 47 & 35.3 & 39 & 29.3 & \\
\hline \multicolumn{6}{|c|}{ Systolic blood pressure (mmHg) } \\
\hline Increased & 49 & 36.8 & 13 & 9.8 & \multirow{2}{*}{$<0.01$} \\
\hline Normal & 84 & 63.2 & 120 & 90.2 & \\
\hline \multicolumn{6}{|c|}{ Diastolic blood pressure (mmHg) } \\
\hline High & 86 & 64.7 & 42 & 31.6 & \multirow{2}{*}{$<0.01$} \\
\hline Normal & 47 & 35.3 & 91 & 68.4 & \\
\hline
\end{tabular}




\begin{tabular}{|c|c|c|c|c|c|}
\hline \multirow{2}{*}{ Variable } & \multicolumn{2}{|c|}{ Enrollment } & \multicolumn{2}{|c|}{ Month 24} & \multirow{2}{*}{$p$ value } \\
\hline & $\mathbf{n}$ & $\%$ & $\mathbf{n}$ & $\%$ & \\
\hline \multicolumn{6}{|l|}{ HDL-cholesterol (mg/dL) } \\
\hline Low & 106 & 79.7 & 119 & 89.5 & \multirow{2}{*}{0.03} \\
\hline Normal & 27 & 20.3 & 14 & 10.5 & \\
\hline \multicolumn{6}{|c|}{ Non HDL-cholesterol (mg/dL) } \\
\hline High & 52 & 39.1 & 57 & 42.9 & \multirow{2}{*}{0.18} \\
\hline Normal & 81 & 60.9 & 76 & 57.1 & \\
\hline \multicolumn{6}{|l|}{ Triglycerides $(\mathrm{mg} / \mathrm{dL})$} \\
\hline High & 77 & 57.9 & 85 & 63.9 & \multirow{2}{*}{0.30} \\
\hline Normal & 56 & 42.1 & 48 & 36.1 & \\
\hline \multicolumn{6}{|c|}{ Fasting blood glucose $(\mathrm{mg} / \mathrm{dL})$} \\
\hline High & 2 & 1.5 & 1 & 0.8 & \multirow{2}{*}{1.00} \\
\hline Normal & 131 & 98.5 & 132 & 99.2 & \\
\hline
\end{tabular}

Source: Childhood Obesity Center.

Notes: $n$ : absolute frequency; $p$ value: McNemar's test; *at the end four were eutrophic

Table 2 - Persistence of metabolic syndrome and association with socioeconomic, demographic and lifestyle variables and with the PDAY (Pathobiological Determinants of Atherosclerosis in Youth) cardiovascular risk score in children and adolescents Childhood Obesity Center, Campina Grande, Paraíba, Brazil, 2012

\begin{tabular}{|c|c|c|c|c|c|c|c|}
\hline \multirow{3}{*}{ Variables } & \multicolumn{4}{|c|}{ Persistence of metabolic syndrome } & \multirow{3}{*}{ RP } & \multirow{3}{*}{$p$ value } & \multirow{3}{*}{$\mathrm{Cl} 95 \%$} \\
\hline & \multicolumn{2}{|c|}{ Yes } & \multicolumn{2}{|c|}{ No } & & & \\
\hline & $\mathbf{n}$ & $\%$ & $\mathbf{n}$ & $\%$ & & & \\
\hline $\mathrm{Sex}_{\text {Male }}$ & & & & 354 & \multirow{2}{*}{1.50} & \multirow[b]{2}{*}{0.26} & \multirow[b]{2}{*}{$0.74-3.06$} \\
\hline Female & 28 & $\begin{array}{l}45.1 \\
54.9\end{array}$ & $\begin{array}{l}29 \\
53\end{array}$ & 64.6 & & & \\
\hline \multicolumn{8}{|l|}{ Age group (years) } \\
\hline Children (2-9) & 15 & 29.4 & 15 & 18.3 & \multirow{2}{*}{1.86} & \multirow{2}{*}{0.14} & \multirow{2}{*}{$0.82-4.24$} \\
\hline Adolescents (10-19) & 36 & 70.6 & 67 & 81.7 & & & \\
\hline \multicolumn{8}{|l|}{ Color } \\
\hline White & 16 & 31.4 & 27 & 32.9 & \multirow{2}{*}{0.93} & \multirow{2}{*}{0.85} & \multirow{2}{*}{$0.44-1.99$} \\
\hline Nonwhites & 35 & 68.6 & 55 & 67.1 & & & \\
\hline \multicolumn{8}{|l|}{ Income* } \\
\hline$\leq$ One minimum salary & 07 & 13.7 & 11 & 13.4 & \multirow{2}{*}{1.03} & \multirow{2}{*}{0.96} & \multirow{2}{*}{$0.37-2.85$} \\
\hline$>$ One minimum salary & 44 & 86.3 & 71 & 86.6 & & & \\
\hline \multicolumn{8}{|l|}{ Maternal education level } \\
\hline$\leq 8$ years of schooling & 27 & 52.9 & 47 & 57.3 & \multirow{2}{*}{0.84} & \multirow{2}{*}{0.62} & \multirow{2}{*}{$0.42-1.69$} \\
\hline$>8$ years of schooling & 24 & 47.1 & 35 & 42.7 & & & \\
\hline Physical activity & & & & & & & \\
\hline$<149$ minutes/week & 26 & 51.0 & 37 & 45.1 & & & \\
\hline$\geq 150$ minutes/week & 25 & 49.0 & 45 & 54.9 & 1.26 & 0.51 & $0.63-2.54$ \\
\hline Sedentarism & & & & & & & \\
\hline Present & 33 & 64.7 & 49 & 59.8 & 124 & 0.57 & $060-255$ \\
\hline Absent & 18 & 35.3 & 33 & 40.2 & 1.24 & $0.5 \%$ & $0.60-2.55$ \\
\hline Nutritional states (z-score) $\dagger$ & & & & & & & \\
\hline Obesity & 47 & 92.2 & 55 & 67.1 & & & $188-1768$ \\
\hline Overweight & 4 & 7.8 & 27 & 32.9 & 5.77 & $<0.01$ & $1.88-17.68$ \\
\hline Non HDL-cholesterol (mg/dL) & & & & & & & \\
\hline Altered & 26 & 51.0 & 31 & 37.8 & 171 & 011 & 0942 \\
\hline Normal & 25 & 49.0 & 51 & 62.2 & $1 . / 1$ & 0.14 & $0.84-3.4 /$ \\
\hline HDL-cholesterol (mg/dL) & & & & & & & \\
\hline Altered & 50 & 98.0 & 69 & 84.1 & 9.42 & 0.01 & $1.19-74.38$ \\
\hline Normal & 1 & 2.0 & 13 & 15.9 & & & \\
\hline Fasting blood glucose $(\mathrm{mg} / \mathrm{dL}$ & & & & & & & \\
\hline Altered & 1 & 2.0 & 0 & 0.0 & & & \\
\hline Normal & 50 & 98.0 & 82 & 100.0 & 2.64 & 0.38 & $2.12-3.28$ \\
\hline Glycated hemoglobin $\mathrm{HbA} 1 \mathrm{c}$ & & & & & & & \\
\hline Altered & 1 & 2.0 & 0 & 0.0 & & & \\
\hline Normal & 50 & 98.0 & 82 & 100.0 & 2.64 & 0.38 & $2.12-3.28$ \\
\hline
\end{tabular}




\begin{tabular}{|c|c|c|c|c|c|c|c|}
\hline \multirow{3}{*}{ Variables } & \multicolumn{4}{|c|}{ Persistence of metabolic syndrome } & \multirow{3}{*}{$\mathbf{R P}$} & \multirow{3}{*}{$p$ value } & \multirow{3}{*}{$\mathrm{Cl} 95 \%$} \\
\hline & \multicolumn{2}{|c|}{ Yes } & \multicolumn{2}{|c|}{ No } & & & \\
\hline & $\mathbf{n}$ & $\%$ & $\mathbf{n}$ & $\%$ & & & \\
\hline \multicolumn{8}{|l|}{ Arterial pressure $(\mathrm{mmHg})$} \\
\hline Altered & 23 & 45.1 & 25 & 30.9 & \multirow{2}{*}{1.84} & \multirow{2}{*}{0.09} & \multirow{2}{*}{$0.89-3.80$} \\
\hline Normal & 28 & 54.9 & 56 & 69.1 & & & \\
\hline \multicolumn{8}{|c|}{ PDAY cardiovascular risk score } \\
\hline Moderate/high risk & 39 & 76.5 & 67 & 81.7 & \multirow{2}{*}{0.73} & \multirow{2}{*}{0.46} & \multirow{2}{*}{$0.31-1.71$} \\
\hline Low risk & 12 & 23.5 & 15 & 18.3 & & & \\
\hline
\end{tabular}

Source: Childhood Obesity Center.

Notes: $n$ : absolute frequency; PR: prevalence ratio; p value: alpha level of .05 (5\%) (Pearson's chi squared test); Cl 95\%: $95 \%$ Confidence interval; *minimum salary in 2012

$=R \$ 622.00 ;$; Four cases of eutrophy were registered at the end of the study; Data regarding smoking were not included in the table because there were no cases of this.

Table 3 - Univariate and multivariate logistic regression, adjusted for age and sex, of the variables associated with persistence of metabolic syndrome, Childhood Obesity Center, Campina Grande, Paraíba, Brazil, 2012

\begin{tabular}{|c|c|c|c|c|c|c|}
\hline $\begin{array}{c}\text { Univariate } \\
\text { Independent variables }\end{array}$ & $\operatorname{Exp}(B)$ & SD & $\mathbf{R}^{2}$ & $\begin{array}{l}\text { Persistence of MetS } \\
p \text { value }\end{array}$ & S CI 95\% & H\&L \\
\hline Nutritional state & 0.182 & 0.575 & 0.139 & 0.003 & $0.059-0.561$ & \multirow{3}{*}{-} \\
\hline Non HDL-cholesterol & 1.915 & 0.373 & 0.060 & 0.082 & $0.921-3.979$ & \\
\hline HDL-cholesterol & 9.247 & 1.061 & 0.103 & 0.036 & $1.157-73.930$ & \\
\hline $\begin{array}{c}\text { Multivariate } \\
\text { Independent variables }\end{array}$ & \multicolumn{6}{|c|}{$\begin{array}{l}\text { Persistence of MetS } \\
p \text { value } \\
\mathrm{Cl} 95 \%\end{array}$} \\
\hline Nutritional state & 0.155 & 0.602 & 0.234 & 0.002 & 0.048-0.505 & \\
\hline Non HDL-cholesterol & 0.446 & 0.409 & & 0.048 & $0.200-0.994$ & 0.537 \\
\hline HDL-cholesterol & 0.119 & 1.081 & & 0.049 & $0.014-0.987$ & \\
\hline
\end{tabular}

Source: Universidade Estadual da Paraíba - UEPB.

Notes: MetS: Metabolic syndrome; EXp(B): regression coefficient (B); SD: standard deviation; $R^{2}$ : Nagelkerke's $R$ squared coefficient ; $p$ value: alpha level of .05 (5\%); CI 95\%: 95\% confidence interval; H\&L: Hosmer-Lemeshow test.

Table 4 - Evaluation of metabolic syndrome persistence and its constituents with the PDAY (Pathobiological Determinants of Atherosclerosis in Youth) cardiovascular risk score, Childhood Obesity Center, Campina Grande, Paraíba, Brazil, 2012

\begin{tabular}{|c|c|c|c|c|c|c|c|}
\hline \multirow{3}{*}{ Metabolic syndrome } & \multicolumn{4}{|c|}{ Cardiovascular risk score - PDAY } & \multirow{3}{*}{$\mathbf{R P}$} & \multirow{3}{*}{$p$ value } & \multirow{3}{*}{$\mathrm{Cl} 95 \%$} \\
\hline & \multicolumn{2}{|c|}{$\mathrm{M} / \mathrm{H}$} & \multicolumn{2}{|c|}{ Low } & & & \\
\hline & $\mathbf{n}$ & $\%$ & $\mathbf{N}$ & $\%$ & & & \\
\hline \multicolumn{8}{|l|}{ Waist circumference (cm) } \\
\hline Altered & 75 & 70.8 & 19 & 70.4 & \multirow{2}{*}{1.02} & \multirow{2}{*}{0.97} & \multirow{2}{*}{$0.40-2.57$} \\
\hline Normal & 31 & 29.2 & 8 & 29.6 & & & \\
\hline \multicolumn{8}{|l|}{ Systolic arterial pressure (mmHg) } \\
\hline Altered & 12 & 11.3 & 1 & 3.7 & \multirow{2}{*}{3.32} & \multirow{2}{*}{0.47} & \multirow{2}{*}{$0.41-26.72$} \\
\hline Normal & 94 & 88.7 & 26 & 96.3 & & & \\
\hline \multicolumn{8}{|l|}{ Diastolic arterial pressure $(\mathrm{mmHg})$} \\
\hline Altered & 42 & 39.6 & 0 & 0 & \multirow{2}{*}{1.42} & \multirow{2}{*}{$<0.01$} & \multirow{2}{*}{$1.24-1.63$} \\
\hline Normal & 64 & 60.4 & 27 & 100.0 & & & \\
\hline \multicolumn{8}{|l|}{ Triglycerides (mg/dL) } \\
\hline Altered & 64 & 60.4 & 21 & 77.8 & \multirow{2}{*}{0.44} & \multirow{2}{*}{0.09} & \multirow{2}{*}{$0.16-1.17$} \\
\hline Normal & 42 & 39.6 & 6 & 22.2 & & & \\
\hline \multicolumn{8}{|l|}{ HDL-cholesterol (mg/dL) } \\
\hline Altered & 98 & 92.5 & 21 & 77.8 & \multirow{2}{*}{3.50} & \multirow{2}{*}{0.04} & \multirow{2}{*}{$1.10-11.15$} \\
\hline Normal & 8 & 7.5 & 6 & 22.2 & & & \\
\hline \multicolumn{8}{|l|}{ Fasting blood glucose (mg/dL) } \\
\hline Altered & 0 & 0 & 1 & 3.7 & \multirow{2}{*}{5.08} & \multirow{2}{*}{0.20} & \multirow{2}{*}{$3.60-7.17$} \\
\hline Normal & 106 & 100.0 & 26 & 96.3 & & & \\
\hline \multicolumn{8}{|l|}{ Persistence of metabolic syndrome } \\
\hline Yes & 39 & 36.8 & 12 & 44.4 & \multirow{2}{*}{0.73} & 0.46 & \\
\hline No & 67 & 63.2 & 15 & 55.6 & & 0.46 & $0.31-1 . / 1$ \\
\hline
\end{tabular}

Source: Childhood Obesity Center.

Notes: M/H: moderate- and high-risk score; Low: low-risk score; PR: prevalence ratio; p value: alpha level of .05 (5\%); CI 95\%: $95 \%$ confidence interval. 
It was verified that PA equal to or greater than 150 minutes per week was reported by $54.9 \%$ of those evaluated and that sedentarism (59.8\%) was higher in the group with persistent MetS. Persistent MetS presented statistically significant associations with nutritional status (PR: $5.77 ; 95 \% \mathrm{Cl}: 1.88-17.68$ ) and HDL-C (PR: 9.42; 95\% Cl: 1.19-74.38) (Table 2).

When tested by multiple regression, only the nutritional status, non-HDL-cholesterol and HDL-cholesterol remained in the adjusted model for age and sex, with a significant association with the persistence of metabolic syndrome (Table 3). Hosmer-Lemeshow test showed no significant results, which indicates the goodness of fit for these variables.

According to the cardiovascular risk classification, 20.3\% (n $=27)$ presented low-risk; $30.1 \%(n=40)$ moderate-risk; while the majority $49.6 \%$ were already at high-risk $(n=66)$. For the purposes of statistical analysis, moderate-risk and high-risk were combined into a single level denominated moderate/high-risk. When the association between persistence of MetS and the constituents of the syndrome with the risk levels was tested, high diastolic blood pressure (PR: 3.50; 95\% Cl: 1.10-11.15) and low HDL-c (PR: 1.42, Cl 95\%: 1.24-1.63) were associated with cardiovascular risk (Table 4). In the multiple analysis, only HDL-cholesterol maintained a statistically significant association, demonstrating that it is an independent marker for cardiovascular risk (ExpB: 0.286; Cl 95\%: 0.09-0.91).

\section{DISCUSSION}

The first study on the prevalence of metabolic syndrome with a sample representative of the Brazilian population was the ERICA (Cardiovascular Risk Study in Adolescents), which showed that the prevalence of MetS varies not only according to the regions, age and sex, but is also associated with socioeconomic status and lifestyle. Since it does not follow a specific pattern, it renders the interpretation of the various relationships found even more complex, while at the same time justifying possible differences with other studies ${ }^{(11)}$. For maternal education level, there was a predominance of eight years or less of schooling, corroborating other studies $^{(7,11)}$, underscoring that the education level of the population is linked to the prevalence of MetS.

The prevalence of MetS was almost double that recorded in $E R I C A^{(11)}$. This finding is justified by the fact that the study worked with the International Diabetes Federation (IDF) criteria, the prevalence from which tends to be lower than those estimated with other definitions that are frequently used, such as NCEP-ATP III, due to the inevitable presence of higher waist circumference in this definition. In addition, when a comparative analysis is performed, it is important to note the lack of consensus regarding the cut-off points for the MetS diagnostic criteria, specifically for the young population, which could justify the discrepancies in prevalence.

The persistence of MetS registered and increase in the prevalence of HDL-cholesterol alterations demonstrate that the risk factors for CVD can begin early in life and that the components of metabolic syndrome are influential factors in this process. It has already been demonstrated that cardiovascular risk (CVR) increases with early onset and duration of the syndrome ${ }^{(8-10)}$.
On the other hand, there was a significant reduction in the indices of blood pressure alterations. This may be associated with guidance given to children and adolescents as part of the care provided by the Child Obesity Center. Modifications in habits introduced during childhood not only improve health conditions at that time, but can become a permanent aspect of their adult life, thereby contributing to the non-development or non-aggravation of MetS, with a corresponding reduction in the number of its components and associated morbidities. Thus, the realization of a plan for weight loss can be considered a means to improve the survival and quality of life in this population.

Although there was no direct association between the persistence of MetS and the PDAY score in this study, there was a marked change in this score, with moderate to high risk in more than $70 \%$ of the sample. Furthermore, the significant association with individual components of this score, such as nutritional status and HDL-C, confirms the severity of the cases.

It is pertinent to point out that blood pressure (BP), lipids profile and anthropometric values vary with age and pubertal stage $^{(16)}$. Excess weight predisposes the risk of CVD, through altered lipid metabolism and blood pressure, which constitutes an atherosclerotic profile in the early stages of life $\mathrm{e}^{(6,28)}$.

In agreement with these findings, other studies such as PDAY ${ }^{(12-13)}$ have demonstrated that high concentrations of LDL and VLDL cholesterol and low HDL levels in children and young adults are associated with an increased risk of early atherosclerotic disease.

With regard to CVDs, their incidence in a cohort study ${ }^{(8)}$ of individuals with pediatric MetS, was $19.4 \%$, compared to $1.5 \%$ for subjects who did not present the syndrome during childhood, while sex, race and family history of CVD showed no relation. However, the presence of MetS in childhood and advancing age were significant predictors for its onset. Moreover, it is important to note that the presence of cardiovascular complications varies from $11.4 \%$ in MetS subjects when compared to $6.1 \%$ in those without the syndrome. This reinforces the hypothesis that increase in age is associated with persistence of MetS, which in turn renders these individuals prone to develop cardiovascular outcomes ${ }^{(28)}$.

Corroborating these findings, other authors ${ }^{(5,9)}$ evaluated the risk factors associated with myocardial infarction, showing that abdominal adiposity is one of the five most relevant factors for this condition in 52 countries, including Brazil. This observation has a substrate in some of the plasmatic markers of obesity ${ }^{(5)}$.

There are few studies on the prevalence of sedentarism among children and adolescents in Brazil, perhaps because of the difficulty of establishing criteria for their evaluation. However, it can be seen that the prevalence of these variables in Brazil was practically unchanged between 2009 and $2012(79.4 \%$ and $78.6 \%$, respectively), with the present study finding even higher levels (83.5\%). Given the diversity of references used, prevalence varies depending on the criteria adopted $^{(29)}$. In this sense, a sedentary lifestyle has a strong influence on the nutritional status of individuals and as part of the obesity cycle it is a key risk factor for metabolic syndrome. Although associations of physical activity (PA) with MetS or CVR have not been found in this study, the protective role of 
PA against cardiovascular events is already well established, since physical exercise leads to an increase in HDL cholesterol and reduction in pressure levels.

The presence of metabolic syndrome components, especially in obese individuals, increases the risk of development and aggravation of comorbidities inherent to this clinical condition. This reality becomes more critical in young individuals, since it predisposes to cardiovascular and metabolic complications in adulthood. Despite the influence of non-modifiable risk factors, such as age, sex, ethnicity and genetics, there are modifiable factors that should be monitored on a greater level as well as a screening strategy to reduce this condition.

In this context, the nursing professionals' role as a member of the multidisciplinary team is of great importance, especially since their performance, in various areas of practice, is highlighted in the process of prevention and health promotion, in addition to continuing education and involving the family members in the context of caring. Nurses can monitor the child's growth, providing early detection of childhood obesity and comorbidities, and provide subsequent assistance and guidance to their legal guardians regarding prevention and treatment.

\section{Study limitations}

It is recognized that there are limitations in the study, since the age range studied was wide (two to 18 years at enrollment), with a stratification in order to ensure the elimination of bias. In this sense, a reduction of the sample is produced in the groups. Another issue is that the behavioral variables were not evaluated in the first stage of the study, which made it impossible to compare them during the study. However, its associations with other aspects that also interfere with cardiovascular health make it possible to infer its effect on health, regardless of the time period. In addition to the risk factors predicted in the study, the advance of research in the area has highlighted the importance of evaluating other independent indicators, as recently pointed out in relation to CVD, especially vitamin D concentrations ${ }^{(29)}$.

\section{Contributions of the study}

The early detection of risk factors for CVD aims to reduce its prevalence, especially among young people. Recognizing risk factors early in life can help health professionals work effectively in the field of prevention by encouraging changes in lifestyle, whatever the age. The management of obesity and associated comorbidities in this age group requires a multiprofessional approach, with the nurse playing an integral role. This study presents an advance in the application of the PDAY cardiovascular risk score, by associating it with the metabolic syndrome and cardiometabolic risk factors in the Brazilian infant and juvenile population.

\section{CONCLUSION}

The majority of children and adolescents were low-income and sedentary, with an already identified high cardiovascular risk. A persistent picture of metabolic syndrome was detected, mostly associated with the independent variables of excess weight, low HDL cholesterol and high non-HDL-cholesterol. Although the persistence of the syndrome has not been shown to be associated with cardiovascular risk as assessed by the PDAY score, the low HDL-cholesterol was shown to be an independent marker for cardiovascular risk.

\section{ACKNOWLEDGMENTS}

The present study was financed by the Universidade Estadual da Paraíba (PROPESQ/UEPB - Processos 098/2008 e 093/2011) and Fundação de Apoio à Pesquisa do Estado da Paraíba (FAPESQ - Processo 198/2008).

\section{REFERENCES}

1. Otto MCO, Afshin A, Renata Micha R, Khatibzadeh S, Fahimi S, Singh G, et al. The impact of dietary and metabolic risk factors on cardiovascular diseases and type 2 diabetes mortality in Brazil. Plos One [Internet]. 2016[cited 2016 May 02];11(3):e0151503. Available from: http://journals.plos.org/plosone/article?id=10.1371/journal.pone.0151503

2. Kyu HH, Pinho C, Wagner JA, Brown JC, Bertozzi-Villa A, Charlson FJ, et al. Global and National Burden of diseases and injuries among children and adolescents between 1990 and 2013: findings from the Global Burden of Disease 2013 Study. JAMA Pediatr [Internet]. 2016[cited 2016 May 02];170(3):267-87. Available from: http://jamanetwork.com/journals/jamapediatrics/fullarticle/2481809

3. Schmidt MI, Duncan BB, Silva GA, Menezes AM, Monteiro CA, Barreto SM, et al. Chronic non-communicable diseases in Brazil: burden and current challenges. Lancet [Internet]. 2011[cited 2016 May 30];377(9781):1949-61. Available from: http://www. thelancet.com/journals/lancet/article/PIIS0140-6736(11)60135-9/abstract

4. Marie Ng, Tom F, Margaret R, Blake T, Nicholas G, Christopher M, et al. Global, regional, and national prevalence of overweight and obesity in children and adults during 1980-2013: a systematic analysis for the Global Burden of Disease Study 2013. Lancet [Internet]. 2013[cited 2016 May 30];384(9945):766-81. Available from: http://www.thelancet.com/pdfs/journals/lancet/PIIS01406736(14)60460-8.pdf

5. Mantovani RM, Rocha NP, Magalhães DM, Barbosa IG, Teixeira AL, Simões e Silva AC. Early changes in adipokines from overweight to obesity in children and adolescents. J Pediatr (Rio J) [Internet]. 2016[cited 2016 Aug 26];92(6):624-30. Available from: http://www.sciencedirect.com/science/article/pii/S0021755716300997

6. Chung IH, Park S, Park MJ, Yoo EG. Waist-to-Height ratio as an index for cardio metabolic risk in adolescents: results from the 1998-2008 KNHANES. Yonsei Med J [Internet]. 2016[cited 2016 Jun 29];57(3):658-63. Available from: https://www.ncbi.nlm.nih. gov/pmc/articles/PMC4800356/pdf/ymj-57-658.pdf 
7. Gronner MF, Bosi PL, Carvalho AM, Casale G, Contrera D, Pereira MA, et al. Prevalence of metabolic syndrome and its association with educational inequalities among Brazilian adults: a population-based study. Braz J Med Biol Res [Internet]. 2011 [cited 2016 Mar 10];44(7):713-9. Available from: http://www.scielo.br/pdf/bjmbr/v44n7/997.pdf

8. Morrison JA, Friedman LA, Gray-McGuire C. Metabolic syndrome in childhood predicts adult cardiovascular disease 25 years later: the Princeton lipid research clinics follow-up study. Pediatrics [Internet]. 2007[cited 2016 Mar 10];120(2):340-5. Available from: http://pediatrics.aappublications.org/content/120/2/340

9. Zalesin KC, Franklin BA, Miller WM, Peterson ED, McCullough PA. Impact of obesity on cardiovascular disease. Med Clin North Am [Internet]. 2011[cited 2016 Mar 2016];95(5):919-37. Available from: http://www.medical.theclinics.com/article/ S0025-7125(11)00063-0/fulltext

10. Nadeau KJ, Maahs DM, Daniels SR, Eckel RH. Childhood obesity and cardiovascular disease: links and prevention strategies. Nat Rev Cardiol [Internet]. 2011[cited 2016 Apr 03];8(9):513-25. Available from: https://www.ncbi.nlm.nih.gov/pmc/articles/ PMC4292916/pdf/nihms-653220.pdf

11. Kuschnir MCC, Bloch MK, Szklo M, Klein CH, Barufaldi LA, Abreu GA, et al. ERICA: prevalência de síndrome metabólica em adolescentes brasileiros. Rev Saúde Pública [Internet]. 2016[cited 2016 Apr 03];50(supl-1):11s. Available from: http://www.scielo. br/pdf/rsp/v50s1/pt_0034-8910-rsp-S01518-87872016050006701.pdf

12. Zieske AW, Malcom GT, Strong JP. Natural history and risk factors of atherosclerosis in children and youth: the PDAY study. Pediatr Pathol Mol Med [Internet]. 2002[cited 2016 Apr 03];21(2):213-37. Available from: http://www.tandfonline.com/doi/abs/10.1080/ pdp.21.2.213.237? journalCode $=$ ipdp19

13. McMahan CA, Gidding SS, Viikari JS, Juonala M, Kähönen M, Hutri-Kähönen N, et al. Association of Pathobiologic Determinants of Atherosclerosis in Youth risk score and 15-year change in risk score with carotid artery intima-media thickness in young adults (from the Cardiovascular Risk in Young Finns Study). Am J Cardiol [Internet]. 2007[cited 2016 Apr 03];100(7):1124-9. Available from: https://www.ncbi.nlm.nih.gov/pmc/articles/PMC2700359/

14. Brasil. Ministério da Saúde. Ministério do Planejamento, Orçamento e Gestão. Pesquisa Nacional de Saúde do Escolar 2012 [Internet]. Rio de Janeiro: IBGE; 2013[cited 2016 Apr 03]. Available from: http://biblioteca.ibge.gov.br/visualizacao/livros/liv64436.pdf

15. Briceño G, Fernández M, Céspedes J. [High prevalence of cardiovascular disease risk factors in a pediatric population]. Biomedica [Internet]. 2015[cited 2016 Apr 04];35(2):219-26. Available from: http://www.scielo.org.co/pdf/bio/v35n2/v35n2a10.pdf Spanish

16. Prado Junior PP, de Faria FR, de Faria ER, Franceschini Sdo C, Priore SE. Cardiovascular risk and associated factors in adolescents. Nutr Hosp [Internet]. 2015[cited 2016 Apr 07];32(2):897-904. Available from: http://www.aulamedica.es/nh/pdf/8824.pdf

17. Senkevics AS, Machado TS, Oliveira AS. A cor ou raça nas estatísticas educacionais: uma análise dos instrumentos de pesquisa do Inep. Série Documental INEP; 2016;41:1-48.

18. Slagter SN, Van Vliet-Ostaptchouk JV, Vonk JM, Boezen HM, Dullaart RP, Kobold AC, et al. Combined effects of smoking and alcohol on metabolic syndrome: the LifeLines cohort study. PLoS One [Internet]. 2014[cited 2016 Apr 07];9(4):e96406. Available from: http://journals.plos.org/plosone/article?id = 10.1371/journal.pone.0096406

19. World Health Organization. WHO. Physical Status: the study and interpretation of anthropometry: report of a WHO expert committee [Internet]. Geneva: WHO, 1995[cited 2016 Mar 14];(854). Available from: http://apps.who.int/iris/bitstream/10665/37003/1/ WHO_TRS_854.pdf

20. Gardner AW, Parker DE, Krishnan S, Chalmers LJ. Metabolic syndrome and daily ambulation in children, adolescents, and young adults. Med Sci Sports Exerc [Internet]. 2013[cited 2016 May 17]; 45(1):163-9. Available from: https://www.ncbi.nlm.nih.gov/ pmc/articles/PMC3521853/

21. Fernández J, Redden D, Pietrobelli A, Allison DB. Waist circumference percentiles in nationally representative samples of AfricanAmerican, European-American, and Mexican-American children and adolescents. J Pediatr [Internet]. 2004 [cited 2016 May 15];145:439-44. Available from: https://www.ncbi.nlm.nih.gov/pubmed/15480363

22. Onis M, Onyango AW, Borghi E, Siyam A, Nishida C, Siekmann J. Development of a WHO growth reference for school-aged children and adolescents. Bull World Health Organ [Internet]. 2007[cited 2016 May 17];85(9):660-7. Available from: http://www. scielosp.org/pdf/bwho/v85n9/a10v85n9.pdf

23. World Health Organization. WHO. Multicentre Growth Reference Study Group. WHO Child Growth Standards: growth velocity based on weight, length and head circumference: methods and development. Geneva: WHO [Internet]. 2009[cited 2016 Mar 14]. Available from: http://www.who.int/childgrowth/standards/velocity/tr3_velocity_report.pdf?ua =1

24. Sociedade Brasileira de Cardiologia. SBC. Sociedade Brasileira de Hipertensão. Sociedade Brasileira de Nefrologia. VI Diretrizes Brasileiras de Hipertensão. Arq Bras Cardiol [Internet]. 2010[cited 2016 May 17];95(1supl1):1-51. Available from: http:// publicacoes.cardiol.br/consenso/2010/Diretriz_hipertensao_associados.pdf

25. Spagnolo A, Giussani M, Ambruzzi AM, Bianchetti M, Maringhini S, Matteucci MC, et al. Focus on prevention, diagnosis and treatment of hypertension in children and adolescents. Ital J Pediatr [Internet]. 2013[cited 2016 May 20];39:20. Available from: https://www.ncbi.nlm.nih.gov/pmc/articles/PMC3615950/pdf/1824-7288-39-20.pdf

26. Xavier HT, Izar MC, Faria Neto JR, Assad MH, Rocha VZ, Sposito AC, et al. V Diretriz Brasileira de Dislipidemias e Prevenção da Aterosclerose. Arq Bras Cardiol [Internet]. 2013[cited 2016 May 15];101(4Suppl1):1-20. Available from: http://www.scielo.br/pdf/ 
abc/v101n4s1/v101n4s1.pdf

27. NECP-ATP III. National Cholesterol Education Program (NCEP). Expert Panel on Detection, Evaluation, and Treatment of High Blood Cholesterol in Adults. Executive Summary of The Third Report of The National Cholesterol Education Program (NCEP) Expert Panel on Detection, Evaluation, And Treatment of High Blood Cholesterol In Adults (Adult Treatment Panel III). JAMA [Internet]. 2001 [cited 2016 Feb 29];285(19):2486-97. Available from: https://www.nhlbi.nih.gov/files/docs/guidelines/atp3xsum.pdf

28. Moreira GC, Cipullo JP, Ciorlia LA, Cesarino CB, Vilela-Martin JF. Prevalence of metabolic syndrome: association with risk factors and cardiovascular complications in an urban population. PLoS One [Internet]. 2014[cited 2016 Apr 03];9(9):e105056. Available from: http://journals.plos.org/plosone/article?id=10.1371/journal.pone.0105056

29. Petersen RA, Dalskov SM, Sørensen LB, Hjorth MF, Andersen R, Tetens I, et al. Vitamin D status is associated with cardiometabolic markers in 8-11-year-old children, independently of body fat and physical activity. Br J Nutr [Internet]. 2015 [cited 2016 Jul 13];114(10):1647-55. Available from: https://www.ncbi.nlm.nih.gov/pubmed/26382732 